\title{
Clone wars: asexual reproduction dominates in the invasive range of Tubastraea spp. (Anthozoa: Scleractinia) in the South-Atlantic Ocean
}

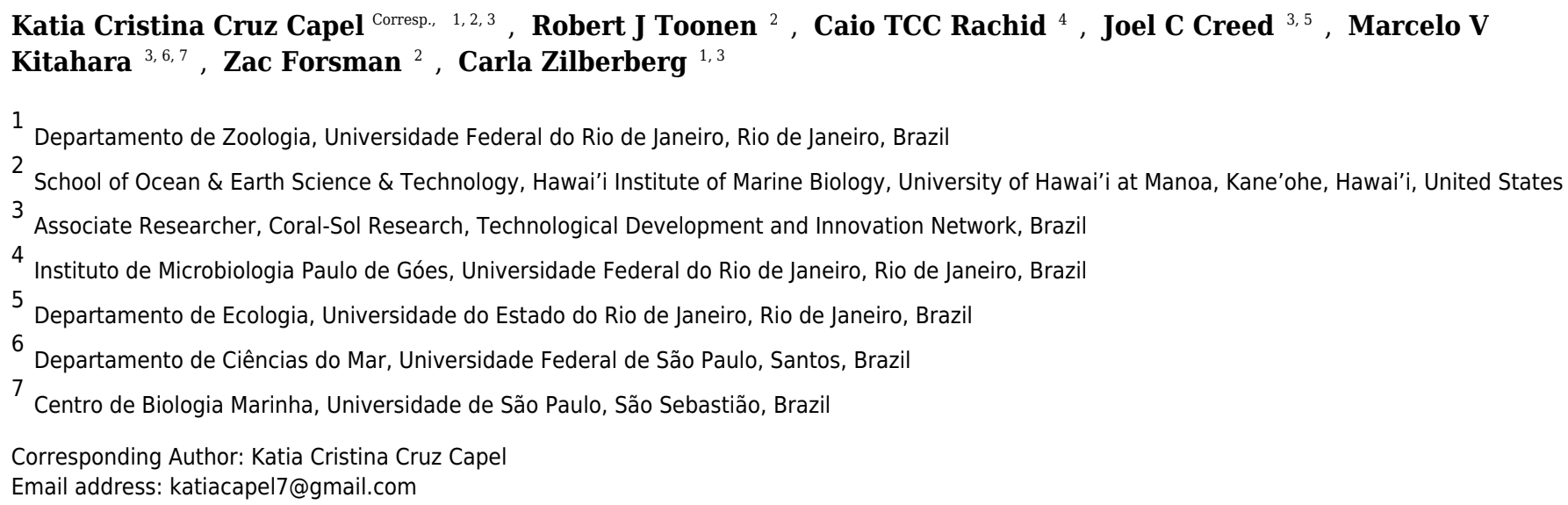

Although the invasive azooxanthellate corals Tubastraea coccinea and T. tagusensis are spreading quickly and outcompeting native species in the Atlantic Ocean, there is little information regarding the genetic structure and path of introduction for these species. Here we present the first data on genetic diversity and clonal structure from these two species using a new set of microsatellite markers. High proportions of clones were observed, indicating that asexual reproduction has a major role in the local population dynamics and, therefore, represents one of the main reasons for the invasion success. Although no significant population structure was found, results suggest the occurrence of multiple invasions for $T$. coccinea and also that both species are being transported along the coast by vectors such as oil platforms and monobouys, spreading these invasive species. In addition to the description of novel microsatellite markers, this study sheds new light into the invasive process of Tubastraea. 
1 Clone wars: asexual reproduction dominates in the invasive range of Tubastraea spp.

2 (Anthozoa: Scleractinia) in the South-Atlantic Ocean

3

4 Kátia CC Capel ${ }^{1,2,3^{*}}$, Robert J Toonen², Caio TCC Rachid ${ }^{4}$, Joel C. Creed ${ }^{3,5}$, Marcelo Kitahara ${ }^{3,6,7}$, 5 Zac H Forsman ${ }^{2}$, Carla Zilberberg ${ }^{1,3}$

6

$7 \quad{ }^{1}$ Departamento de Zoologia, Universidade Federal do Rio de Janeiro, Rio de Janeiro, Brazil

$8 \quad{ }^{2}$ School of Ocean \& Earth Science \& Technology, Hawai'i Institute of Marine Biology, University of

9 Hawai'i at Mānoa, Kāne'ohe, Hawai'I, United States

$10{ }^{3}$ Associate Researcher, Coral-Sol Research, Technological Development and Innovation Network

$11{ }^{4}$ Instituto de Microbiologia Paulo de Góes, Universidade Federal do Rio de Janeiro, Rio de Janeiro,

12 Brazil

$13{ }^{5}$ Departamento de Ecologia, Universidade do Estado do Rio de Janeiro, Rio de Janeiro, Brazil

${ }^{6}$ Departamento de Ciências do Mar, Universidade Federal de São Paulo, Santos, Brazil

$15{ }^{7}$ Centro de Biologia Marinha, Universidade de São Paulo, São Sebastião, Brazil

* Corresponding author

Kátia Capel

e-mail:katiacapel7@gmail.com

Laboratório de Biodiversidade de Cnidária. Departamento de Zoologia

22 Universidade Federal do Rio de Janeiro. 


\begin{abstract}
24 Abstract
25

26

Although the invasive azooxanthellate corals Tubastraea coccinea and T. tagusensis are

27 spreading quickly and outcompeting native species in the Atlantic Ocean, there is little

28 information regarding the genetic structure and path of introduction for these species. Here we

29 present the first data on genetic diversity and clonal structure from these two species using a new

30 set of microsatellite markers. High proportions of clones were observed, indicating that asexual

31 reproduction has a major role in the local population dynamics and, therefore, represents one of

32 the main reasons for the invasion success. Although no significant population structure was

33 found, results suggest the occurrence of multiple invasions for $T$. coccinea and also that both

34 species are being transported along the coast by vectors such as oil platforms and monobouys,

35 spreading these invasive species. In addition to the description of novel microsatellite markers,

36 this study sheds new light into the invasive process of Tubastraea.
\end{abstract}




\section{Introduction}

The marine environment is continuously subjected to multiple stressors, many of which are associated with human activities (e.g. over-exploitation of resources, pollution, climate change and invasive species) (Halpern et al. 2014; Gallardo et al. 2016). Among these stressors, invasive species are considered to be a major threat to biodiversity (Molnar et al. 2008) with the potential to quickly trigger changes in native communities and the ecosystem services and functions, which can have wide-ranging negative impacts. There are numerous examples of marine invasions which impact humans or native biota, such as in the Mediterranean Sea with the invasion of the ctenophore Mnemiopsis leidyi, which caused the collapse of the fishing industry (Shiganova, 1998), the algae Womersleyella setacea, that negatively affected sponge reproduction (Caralt and Cebrian 2013) and the lionfish Pterois spp., responsible for a reduction in the native fish recruitment in the Atlantic (Albins and Hixon 2008).

Scleractinian corals are known to play a key role in the marine environment by building structurally complex and highly diverse ecosystems (Reaka-Kudla 1997). As ecosystem engineers that are under threat globally (Hoegh-Guldberg 1999; Pandolfi et al. 2003), scleractinian corals are rarely seen as an environmental risk. However, three scleractinian species from the genus Tubastraea were introduced and are spreading rapidly throughout the Western Atlantic Ocean (de Paula and Creed 2004; Fenner and Banks 2004; Sammarco et al. 2004; Sammarco et al. 2010; Capel 2012; Sampaio et al. 2012; Costa et al. 2014; Silva et al. 2014), threatening native and endemic species (Mantelatto et al. 2011; Santos et al. 2013; Creed 2006) and fouling manmade structures and vessels.

Tubastraea is an azooxanthellate dendrophyllid genus from the Pacific and Indian Oceans that was first reported in the Caribbean in 1943 (Vaughan and Wells 1943). Since then, three species have been identified in the Western Atlantic Ocean: 1) T. coccinea, now reported along 9,000 $\mathrm{km}$ of coastline of the Western Atlantic Ocean from Florida (26 $47^{\prime} \mathrm{N}, 80^{\circ} 02^{\prime} \mathrm{W}$ ) (Fenner and Banks 2004) to Southern Brazil (27 $\left.{ }^{\circ} 17^{\prime} \mathrm{S}, 4^{\circ} 22^{\prime} \mathrm{W}\right)$ (Capel 2012); 2) T. tagusensis, along the Brazilian coast (de Paula and Creed 2004); and 3) T. micranthus in the Gulf of Mexico (Sammarco et al. 2010). All three are considered opportunistic species most likely associated with transport on ships and/or oil platforms in the Caribbean, Gulf of Mexico and Brazilian coast (Cairns 2000; Castro and Pires 2001; Sammarco et al. 2010). 
Once established, invasive species can alter the structure of local communities, displacing and outcompeting native species (Vitousek 1990; Mooney and Cleland 2001; Lages et al. 2011; Cure et al. 2012; Santos et al. 2013; Miranda et al. 2016). In contrast to the native range, where Tubastraea is largely restricted to shaded or marginal habitats, studies on oilrigs in the Gulf of Mexico have shown that both $T$. coccinea and $T$. micranthus are excellent competitors and can overgrow other species (Hennessey and Sammarco 2014; Sammarco et al. 2015). Similarly, in Brazil, T. coccinea and T. tagusensis can cover up to $100 \%$ of the available surface in some areas (Mantelatto et al. 2011), killing native and endemic coral species upon direct contact (Creed, 2006; Santos et al. 2013; Mantellato et al. 2014; Miranda et al. 2016).

Fast growth rate, rapid range expansion, early reproductive age, propagule pressure and a wide variety of reproductive and survival strategies are biological characteristics usually associated with invasion success (Sax and Brown 2000; Sakai et al. 2001; Lockwood et al. 2005; Sax et al. 2007). Tubastraea species possess all of these characteristics (Cairns 1991, Ayre and Resing 1986; Glynn et al. 2008; Harrison 2011; Capel et al. 2014; de Paula et al. 2014), which are enhanced by the fact that within the invaded areas they generally lack natural predators and dominant competitors. In addition, a large number of infested vectors (e.g. oil platforms and monobuoys) have been recorded transporting Tubastraea spp. along the Brazilian coast, leading to rapid range expansion throughout the Southwestern Atlantic Ocean (Creed et al. 2016).

Asexual reproduction improves coral ability to reach high abundance (Ayre and Miller 2004) and may be an important trait of many invasive species, mainly in the first stage of invasion (Taylor and Hastings 2005). When associate with early reproductive age and high propagule pressure it can rapidly increase abundance. Asexual production of brooded planulae has been reported in several anthozoans, including actinarians (Ottaway and Kirby 1975; Black and Johnson 1979), octocorals (Brazeau and Lasker 1989) and scleractinians (Stoddart 1983; Ayre and Resing 1986). Although T. coccinea and T. diaphana appear to reproduce mainly by asexually produced larvae (Ayre and Resing1986), there is no information for their congeners, and the proportion of sexual versus asexual reproduction remains unknown within the genus. Furthermore, Ayre and Resing (1986) were able to score only two allozyme loci to infer asexual production of brooded larvae of Tubastraea spp. and the use of a larger number of more polymorphic loci, such as microsatellites, is desirable to corroborate their findings. 
98

99

100

101

102

103

104

105

106

107

108

109

110

111

112

113

114

115

116

117

118

119

120

121

122

123

124

125

126

127

128

Although Tubastraea species are spreading rapidly and changing local benthic communities throughout the tropical Western Atlantic, information about their genetic diversity and reproductive strategies are still scarce. The study of reproductive strategies of invasive species is fundamental to understanding the invasion process, preventing new invasions, development of effective management strategies, and resolving the ecological and evolutionary processes involved in their invasion success (Sakai et al. 2001; Sax et al. 2007). However, to date there was no molecular marker developed to perform such studies with Tubastraea. Here, we report 12 novel microsatellite loci specifically developed for $T$. coccinea and cross-amplified in T. tagusensis and investigate the clonal structure and genetic diversity of populations of these alien invasive corals in the Southwestern Atlantic Ocean.

\section{Materials and Methods}

\subsection{Sampling and DNA Extraction}

Microsatellite development was performed using samples of $T$. coccinea collected from

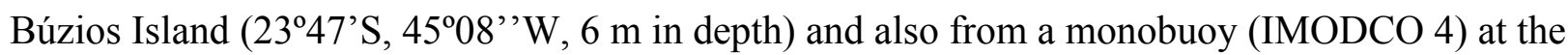
São Sebastião channel ( $23^{\circ} 48^{\prime} \mathrm{S}, 4^{\circ} 24^{\prime} \mathrm{W}, 5 \mathrm{~m}$ of depth), Brazil. Additional samples of $T$. coccinea and T. tagusensis, collected from Todos-os-Santos Bay (TSB), northeastern Brazil (12 $\left.49^{\prime} \mathrm{S}, 38^{\circ} 46^{\prime} \mathrm{W}\right)$, and Ilha Grande Bay (IGB) $\left(23^{\circ} 06^{\prime} \mathrm{S}, 44^{\circ} 15^{\prime \prime} \mathrm{W}\right)$, southeastern Brazil ( 24 colonies / species / locality), were used to test the markers and evaluate their genetic diversity (Figure 1). Samples were preserved in 96\% ethanol or CHAOS buffer (Fukami et al. 2004) prior to extraction. Total DNA was extracted using the Qiagen DNeasy tissue and blood kit following the manufacturer's instructions or using the Phenol:Chloroform method described by Fukami et al. (2004).

\subsection{Microsatellite development and primer testing}

Two genomic libraries were constructed at the National Laboratory for Scientific Computing (LNCC, Petrópolis, Brazil) using the 454 Genome Sequencer FLX platform (Fernandez-Silva et al. 2013). Reads were trimmed for adapters and quality using the FASTXToolkit. The software Newbler 2.3 (Roche) was used to perform the de novo assembly. The programs MSATCOMMANDER 0.8 (Faircloth 2008) and SSRfinder were used to search for di-, 
129 tri-, tetra-, penta-, and hexa-nucleotide repetitions. Thirty-nine pairs of primers flanking the

130 microsatellite regions were designed using Primer3 (http://bioinfo.ut.ee/primer3-0.4.0/) and

131 primer characteristics were checked using OligoAnalyzer 3.1

132 (https://www.idtdna.com/calc/analyzer/). Forward primers were designed with a M13 tail at their

133 5' end (TGT AAA ACG ACG GCC AGT) for dye labeled (6-FAM, VIC, NED, or PET) primers

134 annealing to the replicated strand during PCR reactions (Schuelke 2000).

135 A total of 47 specimens of $T$. coccinea and 48 T. tagusensis were amplified by Polymerase

136 Chain Reactions (PCRs). PCRs were performed in $10 \mu$ reactions including $0.2 \mu \mathrm{M}$ of forward

137 primer with M13 tail, $0.4 \mu \mathrm{M}$ of labeled primer (M13 with VIC, NED, PET, or 6-FAM

138 fluorescent dyes), $0.8 \mu \mathrm{M}$ of reverse primer, 1U GoTaq (Promega), 1X PCR Buffer (Promega),

$1390.20 \mathrm{mM}$ dNTPs (Invitrogen), between 1.5 and $2.5 \mathrm{mM} \mathrm{MgCl}_{2}$ (Table 1), $10 \mu \mathrm{g} \mathrm{BSA}$

140 (Invitrogen), and 5-10 ng of DNA. Cycling conditions were: $95^{\circ} \mathrm{C}$ for $3 \mathrm{~min}$ followed by 5

141 cycles at $95^{\circ} \mathrm{C}, 30 \mathrm{~s} ; 52-62^{\circ} \mathrm{C}$ (Table 1 ), $30 \mathrm{~s} ; 72^{\circ} \mathrm{C}, 45 \mathrm{~s}$; and 30 cycles at $92^{\circ} \mathrm{C}, 30 \mathrm{~s} ; 52-62^{\circ} \mathrm{C}$,

$14230 \mathrm{~s} ; 72^{\circ} \mathrm{C}, 55 \mathrm{~s}$; with a final extension at $72^{\circ} \mathrm{C}$ for $30 \mathrm{~min}$ (Toonen 1997). Amplification was

143 verified in 2\% agarose gel. PCR products were pooled with GS600-LIZ size standard (Applied

144 Biosystems) and genotyped in the ABI 3500 genetic Analyzer (Applied Biosystems). Genotypes

145 were determined using the program Geneious 7.1.9.

\subsection{Statistical analyses}

Clonal structure of each species was assessed using the 'GenClone' on R 3.2.3 package ( $\mathrm{R}$ Development Core Team 2015). Samples with the same alleles at all loci (ramets) were assigned to the same multilocus genotype (MLG, or genets) and considered to be a product of asexual reproduction. To check if individuals with the same MLG were truly clones, the probability of finding identical MLGs, resulting from distinct sexual reproductive events $\left(P_{\text {sex }}\right)$, was calculated following Arnaud-Haond et al. (2007). When $P_{\text {sex }}<0.001$, samples are considered ramets belonging to the same genet. In order to avoid the overestimation of genotype numbers due to scoring errors or somatic mutations (Douhovnikoff and Dodd 2003), a second analysis calculating the genetic distance among all pairs of genets was performed. Based on the genetic distances, MLGs that differed at only one allele were assigned to the same multi-locus Lineage (MLL) (Arnaud-Haond et al. 2007). For the genetic diversity and population structure analyses, only unique MLLs were considered. 
To assess the clonal structure of each population, two indexes were calculated as proposed

161

162

163

164

165

166

167

168

169

170

171

172

173

174

175

176

177

178

179

180

181

182

183

184

185

186

187

188

189

190

by Arnaud-Haond et al. (2007): (1) clonal richness, to evaluate the proportions of clones in each population $(R=G-1 / N-1)$, where $\mathrm{G}$ represents distinct multilocus lineages (MLL) and $\mathrm{N}$ is the total number of individuals sampled. The index ranges from zero (when all individuals are clones) to one (when all samples analyzed correspond to a different MLL); and (2) the genotypic evenness, to evaluate the equitability in the distribution of the MLL, calculated by the Simpson's complement evenness index $\left(V=\left(D-D_{\min }\right) /\left(D_{\max }-D_{\min }\right)\right)$, where $D$ represents the observed diversity, $D_{\max }$ the value assumed if all genets have the same number of ramets, and $D_{\min }$ the diversity value when all but one genet has one individual (Hurlbert 1971). This index ranges from zero (when one genet dominates the population) to one (when genets each have the same number of ramets).

Quality control of loci followed Selkoe and Toonen (2006). To assess each population's genetic diversity, the number of alleles ( $\mathrm{Na}$ ), observed (Ho) and expected heterozygosities (He) were calculated using the 'diveRsity' in R 3.2.3 package (R Development Core Team 2015). Significant deviations from Hardy-Weinberg equilibrium (HWE) and linkage equilibrium were tested with the FSTAT program (Goudet 1995). The occurrence of null alleles was investigated using the Micro-Checker program (Van Oosterhout et al. 2004). To measure population structure two indexes were calculated using the programs Genetix (Belkhiret et al. 2004) and GenoDive (Meirmans and Van Tienderen 2004). (1) Wright's fixation index $F_{\mathrm{ST}}$, ranging from 0 , when different populations have identical alleles frequencies, to 1 , when each population has different fixed alleles (Wright 1965). However, when applied to highly polymorphic markers, such as microsatellites, this index never reaches 1 and can underestimate genetic differentiation (Hedrick 1999; Meirmans and Hedrick 2011; Bird et al. 2011). The second measure, (2) Meirmans and Hedrick's differentiation index $G$ ', ${ }_{\mathrm{ST}}$, is a standardized measure rescaled from 0 to 1 based on the maximum value of $G$ ' ${ }^{\text {sT }}$ which simplifies interpretation of the degree of genetic differentiation among populations when using highly polymorphic microsatellite markers (Meirmans and Hedrick 2011; Bird et al. 2011).

A Bayesian analysis was performed to estimate the number of genetic clusters in the dataset using STRUCTURE v. 2.3.4 software (Pritchard et al. 2000) with the admixture ancestry model and correlated allele frequency. The analysis was performed with an initial burn-in of 500,000 cycles followed by 500,000 additional cycles and the number of clusters $(K)$ tested 
191 varied from 1 to 3 with 15 iterations for each $K$-value. A higher range in the number of clusters

192 ( $K$ ranging from 1 to 5 ) was also tested to verify possible substructure within the populations.

193 The most likely $K$-value was estimated by estimating the "log probability of data" for each value

194 of $K($ mean LnP $(K))$ (Pritchard et al. 2000) using STRUCTURE HARVESTER (Earl and

195 vonHoldt 2012). The $\Delta K$ criterion, frequently used in population genetic studies, is applied for

196 datasets with more than two populations and as one of the hypotheses here is that the two

197 localities are one panmitic population, this criterion was not used in the present work (Evanno et

198 al. 2005).

199

200

\section{Results}

201

202

3.1 Characterization of microsatellite markers

203

204

205

206

207

208

209

210

The two 454 runs resulted in a total of 329,832 reads with an average size of $\pm 708.5 \mathrm{bp}$. A total of 1077 regions with 2-6 bp microsatellite repeats with at least 4 units were found. Among these regions, 39 were selected for primer design, based on the size and position of the repeat within the sequence, and the primer characteristics (e.g. lacking primer-dimer formation). Within these, 11 and 10 were successfully amplified and genotyped for Tubastraea coccinea and T. tagusensis respectively (Accession numbers: KY198738- KY198749). While two loci failed to amplify for T. tagusensis (Tco36 and Tco38), this species also exhibited two loci at a single locus with no evidence of linkage disequilibrium between them (Tco32a and Tco32b), so both were included in these analyses.

Evidence for null alleles for $T$. coccinea TSB population was observed in the same two loci (Tco36 and Tco38) that failed to amplify for T. tagusensis. Since both loci had only homozygote genotypes at the two analyzed localities, these loci were removed from the genetic diversity analyses. The loci Tco1 and Tco9 showed evidence of linkage disequilibrium with other loci and were also removed from the remaining analyses. The number of alleles per locus ranged from 1 to 5 in $T$. coccinea and 1 to 4 in T. tagusensis. Between localities, Ho ranged from 0.38 to 1 (TSB) and 0.17 to 1 (IGB) for T. coccinea and from 0.2 to 1 (TSB) and 0 to 1 (IGB) for $T$. tagusensis. He ranged from 0.31 to 0.76 (TSB) and 0.15 to 0.58 (IGB) for T. coccinea and from 0.18 to 0.62 (TSB) and 0 to 0.61 (IGB) for T. tagusensis (Table 1). In general, the observed 
222 up to $100 \%$ of individuals being heterozygous at some loci (Table 1), although no significant

223 deviation from HWE was observed.

224

225

226

227

of T. coccinea and T. tagusensis respectively. Thus, these data do not support the hypothesis of

228 several individuals with the same MLG having originated by chance from distinct sexual

229 reproduction events. A high proportion of clones were observed at both localities for both species (Table 2). For T. coccinea, at TSB of the 23 colonies sampled 13 MLLs were found, while at IGB only six MLLs out of the 24 colonies sampled were found. T. tagusensis had five (at TSB) and three (at IGB) unique MLLs among the 24 sampled colonies at each locality (Table 2). Missing values were considered as different alleles by the program, and although only specimens with missing information at no more than one locus were kept, it is important to note that the final number of MLL might be overestimated slightly.

Clonal richness observed for $T$. coccinea indicates that IGB is mostly composed of clones $(\mathrm{R}=0.22)$, with only six MLLs out of 24 individuals, while TSB has nearly half of the individuals comprised of clones (13 MLL in 23 individuals sampled; $\mathrm{R}=0.55$ ) (Table 2). In addition to the low MLL diversity at IGB, 19 individuals had the same predominant MLL, which was observed by the evenness indexes $\left(\mathrm{V}=1.13^{-16}\right)$. Conversely, the TSB population of $T$. coccinea had more equally distributed MLLs, with the most common one being shared among only 4 individuals $(\mathrm{V}=0.85)$. For $T$. tagusensis, both populations were composed mainly of clones, with very low clonal richness (IGB: $\mathrm{R}=0.09$; TSB: $\mathrm{R}=0.17$ ). Similarly to what was observed for T. coccinea, MLLs were more equally distributed at TSB, with 14 individuals belonging to the same MLL $(\mathrm{V}=0.54)$, while in IGB the most common one was shared among 22 individuals $\left(\mathrm{V}=-1.04^{-16}\right)$.

\subsection{Genetic diversity and population structure}

Only unique MLLs were used to assess genetic diversity and population structure in each species. For both species, TSB had higher number of alleles, allelic richness and number of

251 private alleles compared to IGB, with $T$. coccinea presenting the more accentuated differences

252 (Table 2). There were no significant deficits of heterozygosity; both observed (Ho) and expected 
253 (He) heterozygosity were similar when comparing between localities for both $T$. coccinea (TSB:

2540.80 and 0.56; IGB: 0.77 and 0.45) and T. tagusensis (TSB: 0.67 and 0.43; IGB: 0.64 and 0.37).

255 The inbreeding coefficient $\left(F_{I S}\right)$, although not significant, was negative for both localities and in

256 both species, indicating an excess of heterozygotes (Table 2).

$257 \quad F_{\text {ST }}$ and $G{ }^{\prime}{ }_{\text {ST }}$ values were $0.06(\mathrm{p}=0.08)$ and $0.13(\mathrm{p}=0.07)$ for $T$. coccinea and

258 indistinguishable from zero $(\mathrm{p}=0.69$ and $\mathrm{p}=0.69)$ for $T$. tagusensis. The lack of significant

259 population structure among the sampled localities indicates similar allele frequencies for both

260 species across these sites. Although Bayesian analysis recovered two genetic clusters for $T$.

261 coccinea for both ranges of $K$ tested, these groups are not a function of population structure

262 between localities (Figure 2), but instead, reflect the presence of population structure within each

263 locality. Furthermore, there is no evidence of interbreeding between the two clusters, and the $F_{\text {ST }}$

264 values between these sites is likely a result of the strikingly different proportion of these two

265 groups in each site. In contrast, no clustering was observed between or within localities for $T$.

266 tagusensis, with the most likely $K$ value being one for both ranges of $K$ tested (Figure 2).

267

268

\section{Discussion}

The novel microsatellite markers reported herein will enable further studies regarding the genetic diversity and population structure of Tubastraea spp. corals in the Atlantic and native ranges of these invasive populations. Using these microsatellites, this study shows that both invasive coral species (T. coccinea and T. tagusensis) have high proportions of clones at both localities on the Brazilian coast with identical multilocus lineages (MLLs) found in sites separated by more than $1,500 \mathrm{~km}$. The results indicate that asexual reproduction dominates in the invasive range of Tubastraea spp. in the Southwestern Atlantic and despite the large distance between localities, no significant population structure could be found. In contrast, there are clear signs of population structure across this same region in an endemic spawning coral species (Mussismilia hispida, Azevedo 2015).

Our results support previous work reporting reproduction via asexual larvae in $T$. coccinea (Ayre and Resing 1986). Likewise, the high proportion of clones found at both sampled localities for T. tagusensis indicates likely reproduction by asexual larvae for this species also, a reproductive mode previously recorded for only three scleractinian species: Pocillopora 
284 Indeed, a study on the reproductive strategies of T. coccinea and T. tagusensis in the

285 Southwestern Atlantic observed a small number of spermaries and the presence of embryos and

286 planula at different times of the year, concluding that asexual reproduction could be important

287 for both species (de Paula et al. 2014). For most corals, clonality is a result of mechanical

288 fragmentation due to physical disturbances (Foster et al. 2013; Nakajima et al. 2015). T. coccinea

289 and T. tagusensis, however, are not prone to fragmentation, so the high number of clones

290 observed for both species in this study seems more likely to result from asexually produced

291 larvae. Nevertheless, it is desirable to confirm the production of asexual larvae for both $T$.

292 coccinea and T. tagusensis by performing paternity studies in the future.

293 For invasive species, asexual reproduction can be crucial in the first stage of invasion,

294 when sexual partners are scarce or absent, because it significantly enhances the chances of

295 survival for the colonists (Taylor and Hastings 2005). Successful invasions originating from a

296 few clonal genotypes have been previously recorded for plants (Ren et al. 2005; Liu et al. 2006)

297 and other cnidarians (Reitzel et al. 2008). Asexual reproduction is dominant in the invasive range

298 and it may have contributed to the invasive success of Tubastraea in the Southwestern Atlantic,

299 where the rocky shores provide a suitable habitat and release from enemies (Enemy Release

300 Hypothesis, Keane and Crawley 2002). At IGB both studied coral species have high percentage

301 of clones and an extremely low genotypic evenness, indicating that most colonies are clones

302 belonging to the same genet. Sampling more areas surrounding each collection site is needed to

303 thoroughly examine clonal diversity for these regions, but particularly in TSB where samples

304 were more widely spaced, this observation supports the role of asexual reproduction in

305 increasing local abundance. Gregarious settlement has been previously observed for both $T$.

306 coccinea (Glynn et al. 2008; de Paula et al. 2014) and T. tagusensis (de Paula et al. 2014),

307 although these studies did not determine if the aggregated larvae were sexually or asexually

308 derived. It is noteworthy that T. coccinea has higher numbers of MLLs, clonal richness and

309 genotypic evenness at TSB than at IGB, suggesting increased occurrence of sexual reproduction

310 or a greater number of successful colonists at the former site. Rates of sexual and asexual

311 reproduction can be highly variable among geographic regions in other corals (Baums et al.

312 2006; Noreen et al. 2009; Combosch and Vollmer 2011; Gorospe and Karl 2013), but it remains

313 unknown what governs the difference in the proportion of sexual and asexual reproduction at

314 different localities. Several factors can influence both genotypic and genetic diversity in invasive 
315 species, including the number of invasions, the genetic diversity of the source population(s) and

316 a variety of biological factors, such as the main reproductive strategy adopted by the species

317 (Dlugosch and Parker 2008). Although sexual reproduction might also occur in Tubastraea, the

318 results obtained for $T$. coccinea might be an effect of the occurrence of recent multiple

319 introductions from different native populations (Roman and Darling 2007). Another hypothesis

320 would be the presence of cryptic species, which has been found in other scleractinian corals

321 (Pinzón and Weil 2011; Warner et al. 2015; Nakajima et al. 2017). Morphological analyses

322 combined with molecular data including native populations are necessary to corroborate this

323 hypothesis.

324 A decrease in genetic diversity as a result of a small founding population has been

325 previously recorded for several invasive populations (Roman and Darling 2007; Geller et al.

326 2008; Johnson and Woollacott 2015; Wrange et al. 2016; but see Gaither et al. 2010, 2012 for

327 counter-examples). Here, we report excess of heterozygosity for both populations of both species

328 and the presence of up to $100 \%$ heterozygous individuals at some loci (Table 1). High levels of

329 heterozygosity can result from an isolate-breaking effect, when multiple introductions mix

330 previously separated native populations (Holland 2000; Hamilton 2010). However, in this case,

331 there is no evidence of mixing between the two genetic clusters (Figure 2), indicating that they

332 are not interbreeding. Thus, it seems more likely that TSB and IGB were colonized by different

333 native populations followed by recent transport between localities without sufficient time for

334 them to interbreed, although the possibility of cryptic species that are incapable of interbreeding

335 should also be considered. If the first scenario of introduction by different native populations

336 proves true, the high heterozygosity could be either a result of a founder effect in which the new

337 area was, by chance, colonized by a higher number of heterozygote genotypes, or due to a higher

338 fitness of the heterozygote genotypes, either of which could be propagated by asexual

339 reproduction (De Meeus and Balloux 2005). Alternatively, Gaither et al. (2012) showed that

340 introduced fishes in Hawai' $i$ with a known history actually had higher and more even genetic

341 diversity than was observed in the native range, and such an effect could also explain the

342 observed pattern here. In contrast to what is observed with $T$. coccinea, we recover only a single

343 genetic cluster for $T$. tagusensis between both populations. This single cluster could result from

344 either invasion of both localities from the same source population, or a secondary invasion along

345 the Brazilian coast from the original locality being spread to another. Unlike $T$. coccinea, which 
346 is now considered cosmopolitan (Cairns 2000), T. tagusensis has a restricted distribution (Cairns

347 1991) and may have naturally low genetic diversity. The distinction between these species is 348 reminiscent of the pattern reported by Gaither et al. (2013) in which population structure of 349 species in their native range predicts the diversity and rate of spread in the invasive range. $350 \quad$ Considering that i) both $T$. coccinea and T. tagusensis brood larvae competent for only $351 \sim 18$ days (in aquaria) that typically display gregarious settlement (Glynn et al. 2008; de Paula et 352 al. 2014) and ii) the absence of Tubastraea in extensive areas between the two localities, it is 353 highly unlikely that they are connected through larval dispersal. On the other hand, oil platforms 354 are known to be moved between these regions (Sampaio et al. 2012), and are considered the 355 main vector for the introduction of Tubastraea into the southwestern Atlantic (Castro and Pires 2001; Creed et al. 2016). Thus, our data showing a lack of structure between localities, and the occurrence of shared MLLs for each species among these distant sites, indicate that anthropogenic vectors, such as oil platforms, monobuoys, or other vessels have played an important role in dispersing these alien invasive species, and possibly assisting other species to spread along the coast (Almeida et al. 2015; Creed et al. 2016).

\section{Conclusions}

Invasive Tubastraea spp. are spreading quickly throughout the Atlantic, in some areas covering up to $100 \%$ of the available surface (Mantellato et al. 2011) and outcompeting native and endemic species (Mantelatto et al. 2011; Santos et al. 2013; Creed 2006). Despite this documented impact and concern, little is known about the genetic diversity and reproductive strategies of Tubastraea species globally. This study provides the first survey of genetic diversity and likely reproductive strategies along the southwestern Atlantic coast, demonstrating that asexual reproduction has an important role in the population dynamics of both $T$. coccinea and $T$. tagusensis and is probably a relevant feature leading to their invasive success. Results also indicate that there were likely at least two different populations of $T$. coccinea introduced into the southwestern Atlantic. A molecular systematic examination of the genus is highly recommended in order to check for the occurrence of cryptic species. Future studies should focus on the identification of potential source populations and the global phylogeograpy of Tubastraea with the goal of tracking and limiting future invasions, as well as the establishment of effective management and prevention strategies. 


\section{Acknowledgements}

379 We are grateful to Antonio Solé-Cava for helping editing the first set of Next-Generation

380 Sequencing data and to Marcelo Mantellato and Projeto Coral-Sol for samples. We are also

381 thankful to Diane Bailleul for all the support on the clonal analyses. This is Scientific

382 Contribution No. 30 of the Projeto Coral-Sol.

383

384

385

386

387

388

389

390

391

392

393

394

395

396

397

398

399

400

401

402

403

404

\section{References}

Albins MA, Hixon MA (2008) Invasive Indo-Pacific lionfish Pterois volitans reduce recruitment of Atlantic coral-reef fishes. Marine Ecology Progress Series 367:233-238. https://doi.org/10.3354/meps07620

Almeida ACS, Souza FBC, Gordon DP, Vieira LM (2015) The non-indigenous bryozoan Triphyllozoon (Cheilostomata: Phidoloporidae) in the Atlantic: morphology and dispersion on the Brazilian coast. Zoologia (Curitiba) 32:476-484.

Arnaud-Haond S, Duarte M, Alberto F, Serrão A (2007) Standardizing methods to address clonality in population studies. Molecular Ecology 16:5115-5139. doi: 10.1111/j.1365294X.2007.03535.X

Ayre DJ, Miller KJ (2004) Where do clonal coral larvae go? Adult genotypic diversity conflicts with reproductive effort in the brooding coral Pocillopora damicornis. Marine Ecology Progress Series 277:95-105. doi: 10.3354/meps277095

Ayre DJ, Resing JM (1986) Sexual and asexual production of planulae in reef corals. Marine Biology 90:187-190. doi: 10.1007/BF00569126

Azevedo LP (2015) Conectividade genética do coral endêmico Mussismilia hispida

(Scleractinia: Mussidae) ao longo da costa brasileira. Master's dissertation. Universidade Federal do Rio de Janeiro

Baums IB, Miller MW, Hellberg ME (2006) Geographic variation in clonal structure in a reefbuilding Caribbean coral, Acropora palmata. Ecologial Monographs 76:503-519. doi: 10.1890/0012-9615(2006)076[0503:GVICSI]2.0.CO;2 
405

406

407

408

409

410

411

412

413

414

415

416

417

418

419

420

421

422

423

424

425

426

427

428

429

430

431

432

433

434

Belkhir K, Borsa P, Chikhi L, Raufaste N, Bonhomme F (2004) Genetix 4.04, logiciel sous

\begin{abstract}
Windows TM por la génétique des populations. Laboratoire Génome, Populations,
\end{abstract} Interactions, CNRS UMR 500, Université de Montpelier II, Montpellier

Bird CE, Karl S, Smouse PE, Toonen RJ (2011) Detecting and measuring genetic differentiation. In: Koenemann S, Held C, Schubart C (ed) Crustacean Issues: phylogeography and population genetics in Crustacea. CRC Press, Boca Raton, pp. 31-55

Black R. Johnson MS (1979) Asexual viviparity and population genetics of Actinia tenebrosa. Marine Biology 53:27-31. doi: 10.1007/BF00386526

Brazeau, D.A. and H.R. Lasker. 1989. The reproductive cycle and spawning in a Caribbean gorgonian. Biological Bulletin 176: 1-7. doi: 10.2307/1541882

Cairns SD (1991) A revision of the ahermatypic scleractinia of the Galapagos and Cocos Islands.

Smithsonian Contributions to Zoology 504:1-32. doi: 10.5479/si.00810282.504

Cairns SD (2000) Studies on the natural history of the Caribbean region. Studies on the fauna of Curaçao and other Caribbean Islands 75

Capel KCC (2012) Scleractinia (Cnidaria: Anthozoa) da Reserva Biológica Marinha do Arvoredo (SC), com ênfase na estrutura espaço-temporal da formação mais meridional de corais recifais no Oceano Atlântico. Master's dissertation. Universidade Federal de Santa Catarina

Capel KC, Migotto AE, Zilberberg C, Kitahara MV (2014) Another tool towards invasion?

Polyp bail-out in Tubastraea coccinea. Coral Reefs 33:1165. doi: 10.1007/s00338-014-1200-z

Caralt S, Cebrian E (2013) Impact of an invasive alga (Womersleyella setacea) on sponge assemblages: compromising the viability of future populations. Biological Invasions 15:15911600. doi: 10.1007/s10530-012-0394-7

Castro CB, Pires DO (2001) Brazilian coral reefs: What we already know and what is still missing. Bulletin of Marine Science 69:357-371

Combosch DJ, Vollmer SV (2011) Population genetics of an ecosystem-defining reef coral Pocillopora damicornis in the Tropical Eastern Pacific. PLoS One 6:e21200.

doi:10.1371/journal.pone.0021200

Costa, T.J.F., Pinheiro, H.T., Teixeira, J.B., Mazzei, E.F., Bueno, L., Hora, M.S.C., Joyeux, J.C., Carvalho-Filho A, Amado-Filho G, Sampaio CLS, Rocha LA (2014) Expansion of an 
435

436

437

438

439

440

441

442

443

444

445

446

447

448

449

450

451

452

453

454

455

456

457

458

459

460

461

462

463

464

465

invasive coral species over Abrolhos Bank, Southwestern Atlantic. Marine Pollution Bulletin 85:252-253. doi: 10.1016/j.marpolbul.2014.06.002

Creed JC (2006) Two invasive alien azooxanthellate corals, Tubastraea coccinea and Tubastraea tagusensis, dominate the native zooxanthellate Mussismilia hispida in Brazil. Coral Reefs 25:350. doi: 10.1007/s00338-006-0105-X

Creed JC, Fenner D, Sammarco P, Carins S, Capel K, Junqueira AOR, Cruz I, Miranda RJ, Carlos-Junior L, Mantelatto MC, Oigman-Pszczol S (2016) The invasion of the azooxanthellate coral Tubastraea (Scleractinia: Dendrophylliidae) throughout the world: history, pathways and vectors. Biological Invasions. doi:10.1007/s10530-016-1279-y

Cure K, Benkwitt CE, Kindinger TL, Pickering EA, Pusack TJ, McIlwain JL, Hixon MA (2012) Comparative behavior of red lionfish Pterois volitans on native Pacific versus invaded Atlantic coral reefs. Marine Ecology Progress Series 467:181-192. doi: 10.3354/meps09942

De Meeus T, Balloux F (2005) F-statistics of clonal diploids structured in numerous demes.

Molecular Ecology 14, 2695-2702. doi: 10.1111/j.1365-294X.2005.02643.x

de Paula AF, Creed JC (2004) Two species of the coral Tubastraea (Cnidaria, Scleractinia) in Brazil: a case of accidental introduction. Bulletin of Marine Science 74:175-183.

de Paula AF, Pires DO, Creed JC (2014) Reproductive strategies of two invasive Sun corals (Tubastraea spp.) in the southwestern Atlantic. Journal of the Marine Biological Association of the United Kingdom 94:481-492. doi: 10.1017/S0025315413001446

Dlugosch KM, Parker M (2008) Founding events in species invasions: genetic variation, adaptive evolution, and the role of multiple introductions. Molecular Ecology 17:431-449. doi: 10.1111/j.1365-294X.2007.03538.x

Douhovnikoff V, Dodd RS (2003) Intra-clonal variation and a similarity threshold for identification of clones: application to Salix exigua using AFLP molecular markers. Theoretical and Applied Genetics 106:1307-1315. doi 10.1007/s00122-003-1200-9

Earl DA, vonHoldt BM (2012) STRUCTURE HARVESTER: a website and program for visualizing STRUCTURE output and implementing the Evanno method. Conservation Genetics Resources 4:359-361. doi: 10.1007/s12686-011-9548-7

Evanno G, Regnaut S, Goudet J (2005) Detecting the number of clusters of individuals using the software Structure: a simulation study. Molecular Ecology 14:2611-2620. doi: 10.1111/j.1365-294X.2005.02553.x 
466 Faircloth BC (2008) Msatcommander: detection of microsatellite repeat arrays and automated,

467 locus-specific primer design. Molecular Ecology Resources 8:92-94. doi: 10.1111/j.1471$468 \quad 8286.2007 .01884 . \mathrm{x}$

469 Fenner D (2001) Biogeography of three Caribbean corals (Scleractinia) and the invasion of

470 Tubastraea coccinea into the Gulf of Mexico. Bulletin of Marine Scinece 69:1175-1189

471 Fenner D, Banks K (2004) Orange Cup Coral Tubastraea coccinea invades Florida and the

472 Flower Garden Banks, Northwestern Gulf of Mexico. Coral Reefs 23:505-507. doi:

$473 \quad 10.1007 / \mathrm{s} 00338-004-0422-\mathrm{X}$

474 Fernandez-Silva I, Whitney J, Wainwright B, Andrews KR, Ylitalo-Ward H, Bowen BW,

475 Toonen RJ, Goetze E, Karl SA (2013) Microsatellites for next-generation ecologists: a post-

476 sequencing bioinformatics pipeline. PLoS one, 8:e55990.

477 http://dx.doi.org/10.1371/journal.pone.0055990

478 Foster NL, Baums IB, Sanchez JA, Paris CB, Chollett I, Agudelo CL, Vermeij MJA, Mumby PJ

479 (2013) Hurricane-driven patterns of clonality in an ecosystem engineer: the Caribbean coral

480 Montastraea annularis. PLoS ONE 8:e53283. doi:10.1371/journal.pone.0053283

481 Fukami H, Budd AF, Paulay G, Sole-Cava A, Chen CLA, Iwao K, Knowlton N (2004)

482 Conventional taxonomy obscures deep divergence between Pacific and Atlantic corals. Nature 483 427:832-835. doi: 10.1038/nature02339

484 Gaither MR, Bowen BW, Toonen RJ (2013) Population structure in the native range predicts the 485 spread of introduced marine species. Proceedings of the Royal Society B: Biological Sciences 486 280:20130409. http://dx.doi.org/10.1098/rspb.2013.0409

487 Gaither MR, Bowen BW, Toonen RJ, Planes S, Messmer V, Earle J, Ross Robertson D (2010)

488 Genetic consequences of introducing allopatric lineages of Bluestriped Snapper (Lutjanus

489 kasmira) to Hawaii.Molecular Ecology 19:1107-1121. doi: 10.1111/j.1365-

$490 \quad 294 X .2010 .04535 . x$

491 Gaither MR, Toonen RJ, Bowen BW (2012) Coming out of the starting blocks: Extended lag 492 time rearranges genetic diversity in introduced marine fishes of Hawaii. Proceedings of the

493 Royal Society B: Biological Sciences. 279:3948-3957. doi:10.1098/rspb.2012.1481

494 Gallardo B, Clavero M, Sánchez MI, Vilà M (2016) Global ecological impacts of invasive 495 species in aquatic ecosystems. Global Change Biology 22:151-163. doi: 10.1111/gcb.13004 
496 Geller J, Sotka EE, Kado R, Palumbi SR, Schwindt E (2008) Sources of invasions of a

497 northeastern Pacific acorn barnacle, Balanus glandula, in Japan and Argentina. Marine

498 Ecology Progress Series 358:211-8. doi: 10.3354/meps07466

499 Glynn PW, Colley SB, Mate JL, Cortes J, Guzman HM, Bailey RL, Feingold JS, Enochs IC

500 (2008) Reproductive ecology of the azooxanthellate coral Tubastraea coccinea in the

501 equatorial eastern pacific: Part V. Dendrophylliidae. Marine Biology 153:529-544. doi:

$502 \quad 10.1007 / \mathrm{s} 00227-007-0827-5$

503 Goudet J (1995) FSTAT v.2.9.3.2, a computer program to calculate F-statistics. Journal of 504 Heredity 86:485-486

505 Gorospe KD, Karl SA (2013) Genetic relatedness does not retain spatial pattern across multiple

506 spatial scales: dispersal and colonization in the coral, Pocillopora damicornis. Molecular

507 Ecology 22:3721-3736. doi: 10.1111/mec.12335

508 Halpern BS, Frazier M, Potapenko J, Casey KS, Koenig K, Longo C, Lowndes JS, Rochwood

509 RC, Selig ER, Selkoe KA, Walbridge S (2014) Spatial and temporal changes in cumulative

510 human impacts on the world's ocean. Nature Communications 6:7615. doi:

$511 \quad 10.1038 /$ ncomms 8615

512 Hamilton M (2010) Population genetics. John Wiley \& Sons Inc, New York

513 Harrison PL (2011) Sexual Reproduction of Scleractinian Corals. In: Dubinsky Z, Stambler N

514 (eds) Coral Reefs: An Ecosystem in Transition, Part 3, pp 59-85

515 Hedrick PW (1999) Highly variable loci and their interpretation in evolution and conservation.

516 Evolution 53:313-318. doi: 10.2307/2640768

517 Hennessey SM, Sammarco PW (2014) Competition for space in two invasive Indo-Pacific corals

518 -Tubastraea micranthus and Tubastraea coccinea: Laboratory experimentation. Journal of

519 Experimental Marine Biology and Ecology 459:144-150. doi: 10.1016/j.jembe.2014.05.021

520 Hoegh-Guldberg O (1999) Climate change, coral bleaching and the future of the world's coral

521 reefs. Marine and Freshwater Research, 50:839-866. doi: 10.1071/MF99078

522 Holland BS (2000) Genetics of marine bioinvasions. Hydrobiologia 420:63-71. doi:

$523 \quad 10.1007 / 978-94-017-2184-4 \_7$

524 Hurlbert SH (1971) The nonconcept of species diversity: a critique and alternative parameters.

525 Ecology 52:577-586. doi: 10.2307/1934145 
526 Johnson CH, Woollacott RM (2015) Analyses with newly developed microsatellite markers

527 elucidate the spread dynamics of Tricellaria inopinata d'Hondt and Occhipinti-Ambrogi,

5281985 - a recently established bryozoan along the New England seashore. Aquatic Invasions

529 10:135-145. doi: 10.3391/ai.2015.10.2.02

530 Keane RM, Crawley MJ (2002) Exotic plant invasions and the enemy release hypothesis. Trends

531 in Ecology \& Evolution 17:164-170. http://dx.doi.org/10.1016/S0169-5347(02)02499-0

532 Lages BG, Fleury BG, Menegola C, Creed JC (2011) Change in tropical rocky shore

533 communities due to an alien coral invasion. Marine Ecology Progress Series 438:85-96. doi:

$534 \quad 10.3354 / \operatorname{meps} 09290$

535 Liu J, Dong M, Miao SL, Li ZY, Song MH, Wang RQ (2006) Invasive alien plants in China: role

536 of clonality and geographical origin. Biol. Invasions 8:1461-1470. doi: 10.1007/s10530-005-

$537 \quad 5838-\mathrm{x}$

538 Lockwood JL, Cassey P, Blackburn T (2005) The role of propagule pressure in explaining

539 species invasions. TRENDS in Ecology and Evolution 20:223-228.

540 http://dx.doi.org/10.1016/j.tree.2005.02.004

541 Mantellato MC, Mourão GG, Migotto A, Lindner A (2011) Range expansion of the invasive

542 corals Tubastraea coccinea and Tubastraea tagusensis in the Southwest Atlantic. Coral Reefs

543 30:397. doi: 10.1007/s00338-011-0720-z

544 Mantellato MC, Creed JC (2014) Non-indigenous sun corals invade mussel beds in Brazil.

545 Marine Biodiversity 45:605-606. doi: 10.1007/s12526-014-0282-8

546 Meirmans PG, Van Tienderen PH (2004) GENOTYPE and GENODIVE: two programs for the

547 analysis of genetic diversity of asexual organisms. Molecular Ecology Notes 4:792-794. doi:

$548 \quad 10.1111 / \mathrm{j} .1471-8286.2004 .00770 . \mathrm{x}$

549 Meirmans PG, Hedrick PW (2011) Assessing population structure: FST and related measures.

550 Molecular ecology resources 11:5-18. doi: 10.1111/j.1755-0998.2010.02927.x

551 Miranda RJ, Cruz ICS, Barros F (2016) Effects of the alien coral Tubastraea tagusensis on

552 native coral assemblages in a southwestern Atlantic coral reef. Marine Biodiversity 163:45.

553 doi: $10.1007 / \mathrm{s} 00227-016-2819-9$

554 Molnar JL, Gamboa RL, Revenga C, Spalding MD (2008) Assessing the global threat of

555 invasive species to marine biodiversity. Frontiers in Ecology and the Environment 6:485-492.

556 doi: $10.1890 / 070064$ 
557 Mooney HA, Cleland EE (2001) The evolutionary impact of invasive species. Proceedings of the

558 National Academy of Sciences 98:5446-5451. doi: 10.1073/pnas.091093398

559 Nakajima Y, Shinzato C, Satoh N, Mitarai S (2015) Novel polymorphic microsatellite markers

560 reveal genetic differentiation between two sympatric types of Galaxea fascicularis. PLoS

561 ONE 10:e0130176. doi: 10.1371/journal.pone.0130176

562 Nakajima Y, Nishikawa A, Iguchi A, Nagata T, Uyeno D, Sakai K, Mitarai S (2017) Elucidating

563 the multiple genetic lineages and population genetic structure of the brooding coral

564 Seriatopora (Scleractinia: Pocilloporidae) in the Ryukyu Archipelago. Coral Reefs 36:415-

565 426. doi: 10.1007/s00338-017-1557-x

566 Noreen AME, Harrison PL, Van Oppen JH (2009) Genetic diversity and connectivity in a

567 brooding reef coral at the limit of its distribution. Proceedings of the Royal Society B

568 276:3927-3935. doi: 10.1098/rspb.2009.1050

569 Ottaway JR, Kirby GC (1975) Genetic relationships between brooding and brooded Actinia

570 tenebrosa. Nature 255:221-223. doi: 10.1038/255221a0

571 Pandolfi JM, Bradbury RH, Sala R, Hughes TP, Bjorndal KA, Cooke RG, McArdle D,

572 McClenachan L, Newman MJH, Paredes G, Warner RR, Jackson JBC (2003) Global

573 Trajectories of the Long-Term Decline of Coral Reef Ecosystems. Science 301:955. doi:

$574 \quad 10.1126 /$ science. 1085706

575 Pinzón JH, Weil E (2011) Cryptic Species Within the Atlantic-Caribbean Genus Meandrina

576 (Scleractinia): A Multidisciplinary Approach and Description of the New Species Meandrina

577 jacksoni. Bulletin of Marine Science 87:823-853. doi: 10.5343/bms.2010.1085

578 Pritchard JK, Stephens M, Donnelly P (2000) Inference of population structure using multilocus 579 genotype data. Genetics 155:945-959

580 R Core Team (2015) R: A language and environment for statistical computing. R Foundation

581 for Statistical Computing, Vienna, Austria. URL http://www.R-project.org.

582 Reaka-Kudla ML (1997) Global biodiversity of coral reefs: a comparison with rainforests. In:

583 Reaka-Kudla ML, Wilson DE (eds) Biodiversity II: Understanding and Protecting Our

584 Biological Resources. Joseph Henry Press 
585 Reitzel AM, Darling JA, Sullivan JC, Finnerty JR (2008) Global population genetic structure of 586 the starlet anemone Nematostella vectensis: multiple introductions and implications for 587 conservation policy. Biological Invasions 10:1197-1213. doi: 10.1007/s10530-007-9196-8 588 Ren MX, Zhang QC, Zhand DY (2005) Random amplified polymorphic DNA markers reveal 589 low genetic variation and a single dominant genotype in Eichhornia crassipes populations 590 throughout China. Weed Research 45:236-244. doi: 10.1111/j.1365-3180.2005.00445.x 591 Roman J, Darling JA (2007) Paradox lost: genetic diversity and the success of aquatic invasions. 592 Trends Ecology Evolution 22:454-64. doi: http://dx.doi.org/10.1016/j.tree.2007.07.002 593 Sakai AK, Allendorf FW, Holt JS, Lodge DML, Molofsky J, With KA, Baughman S, Cabin RJ, 594 Cohen JE, Ellstrand NC, McCauley DE, O’Neil P, Parker IM, Thompson JN, Weller SG 595 596 597 598 599 600 601 602 603 604 605 606 607 608 609 610 611 612 613 614 (2001) The population biology of invasive species. Annual Review of Ecology, Evolution, and Systematics 32:305-32. doi: 10.1146/annurev.ecolsys.32.081501.114037

Sammarco PW, Atchison AD, Boland GS (2004) Expansion of coral communities within the Northern Gulf of Mexico via offshore oil and gas platforms. Marine Ecology Progress Series 280:129-143. doi: 10.3354/meps280129

Sammarco PW, Porter SA, Cairns SD (2010) A new coral species introduced into the Atlantic Ocean - Tubastraea micranthus (Ehrenberg 1834) (Cnidaria, Anthozoa, Scleractinia): an invasive threat? Aquatic Invasions 5:131-140. doi: 10.3391/ai.2010.5.2.02

Sammarco PW, Porter SA, Genazzio M, Sinclair J (2015) Success in Competition for Space in Two Invasive Coral Species in the western Atlantic - Tubastraea micranthus and T. coccinea. PLoS ONE 10:e0144581. doi: 10.1371/journal.pone.0144581

Sampaio CLS, Miranda RJ, Maia-Nogueira R, Nunes JACC (2012) New occurrences of the nonindigenous orange cup corals Tubastraea coccinea and T. tagusensis (Scleractinia: Dendrophylliidae) in Southwestern Atlantic. Check List 8:528-530. doi: http://dx.doi.org/10.15560/8.3.528

Santos LAH, Ribeiro FV, Creed JC (2013) Antagonism between invasive pest corals Tubastraea spp. and the native reef-builder Mussismilia hispida in the southwest Atlantic. Journal of Experimental Marine Biology and Ecology 449:69-76. doi: 10.1016/j.jembe.2013.08.017

Sax DF, Brown JH (2000) The paradox of invasion. Global Ecology \& Biogeography 9:363-371. doi: $10.1046 / \mathrm{j} .1365-2699.2000 .00217 . \mathrm{x}$ 
615 Sax DF, Stachowick JJ, Brown JH, Bruno JF, Dawson MN, Gaines SD, Grosberg RK, Hastings 616 A, Holt RD, Mayfield MM, O’Connor MI, Rice WR (2007) Ecological and evolutionary 617 insights from species invasions. Trends in Ecology and Evolution 22:465-471. doi:

618 http://dx.doi.org/10.1016/j.tree.2007.06.009

619 Schuelke M (2000) An economic method for the fluorescent labeling of PCR fragments. Nature 620 Biotechnology 18:223-234. doi: 10.1038/72708

621 Selkoe KA, Toonen RJ (2006) Microsatellites for ecologists: a practical guide to using and 622 evaluating microsatellite markers. Ecology Letters 9:615-629. doi: 10.1111/j.1461$623 \quad 0248.2006 .00889 . x$

624 Shiganova TA (1998) Invasion of the Black Sea by the ctenophore Mnemiopsis leidyi and recent 625 changes in pelagic community structure. Fisheries Oceanography 7:305-310. doi:

$626 \quad 10.1046 / \mathrm{j} .1365-2419.1998 .00080 . \mathrm{x}$

627 Silva AG, de Paula AF, Fleury BG, Creed JC (2014) Eleven years of range expansion of two 628 invasive corals (Tubastraea coccinea and Tubastraea tagusensis) through the southwest 629 Atlantic (Brazil). Estuarine, Coastal and Shelf Science 141:9-16. doi:

$630 \quad 10.1016 / \mathrm{j}$. ecss.2014.01.013

631 Stoddart JA (1983) Asexual production of planulae in the coral Pocillopora damicornis. Marine 632 Biology 76:279-284. doi: 10.1007/BF00393029

633 Taylor CM, Hastings A (2005) Allee effects in biological invasions. Ecology Letters 8:895-908. 634 doi: 10.1111/j.1461-0248.2005.00787.x

635 Toonen RJ (1997) Microsatellites for ecologists: non-radioactive isolation and amplification 636 protocols for microsatellite markers. Website http://biogeek. ucdavis. edu/Mstats/.

637 Van Oosterhout C, Hutchinson WF, Wills DPM, Shipley P (2004) Micro-checker: software for 638 identifying and correcting genotyping errors in microsatellite data. Molecular Ecology Notes 639 4:535-538. doi: 10.1111/j.1471-8286.2004.00684.x

640 Vaughan TW, Wells JW (1943) Revision of the suborders, families and genera of the 641 Scleractinia. Geological Society of America Special Papers 44

642 Vitousek PM (1990) Biological invasions and ecosystem processes: towards an integration of 643 population biology and ecosystem studies. Oikos 57:7-13. doi: 10.2307/3565731 
644 Warner PA, van Oppen MJH, Willis BL (2015) Unexpected cryptic species diversity in the 645 widespread coral Seriatopora hystrix masks spatial-genetic patterns of connectivity.

646 Molecular Ecology 24:2993-3008. doi:10.1111/mec.13225

647 Wrange A-L, Charrier G, Thonig A, Rosenblad MA, Blomberg A, Havenhand JN, Jonsson PR, 648 André C (2016) The story of a hitchhiker: population genetic patterns in the invasive barnacle 649 Balanus (Amphibalanus) improvisus Darwin 1854. PLoS ONE 11:e0147082. doi:

$650 \quad 10.1371 /$ journal.pone.0147082

651 Wright S (1965) The interpretation of population structure by F-statistics with special regard to 652 systems of mating. Evolution pp.395-420 


\section{Figure 1}

Distributional range and sample localities on Southwestern Atlantic.

Map showing the distributional range of Tubastraea spp. on Southwestern Atlantic with the northern (NL) and souther (SL) limits of the distribution and sample localities: Todos-osSantos Bay (TSB) and Ilha Grande Bay (IGB) are showed by dark-gray stars; light-gray star represent Búzios Island and São Sebastião channel where initial collections to isolate microsatellite loci were performed. Map layout from http://d-maps.com/carte.php?num_car=1521\&lang=en 


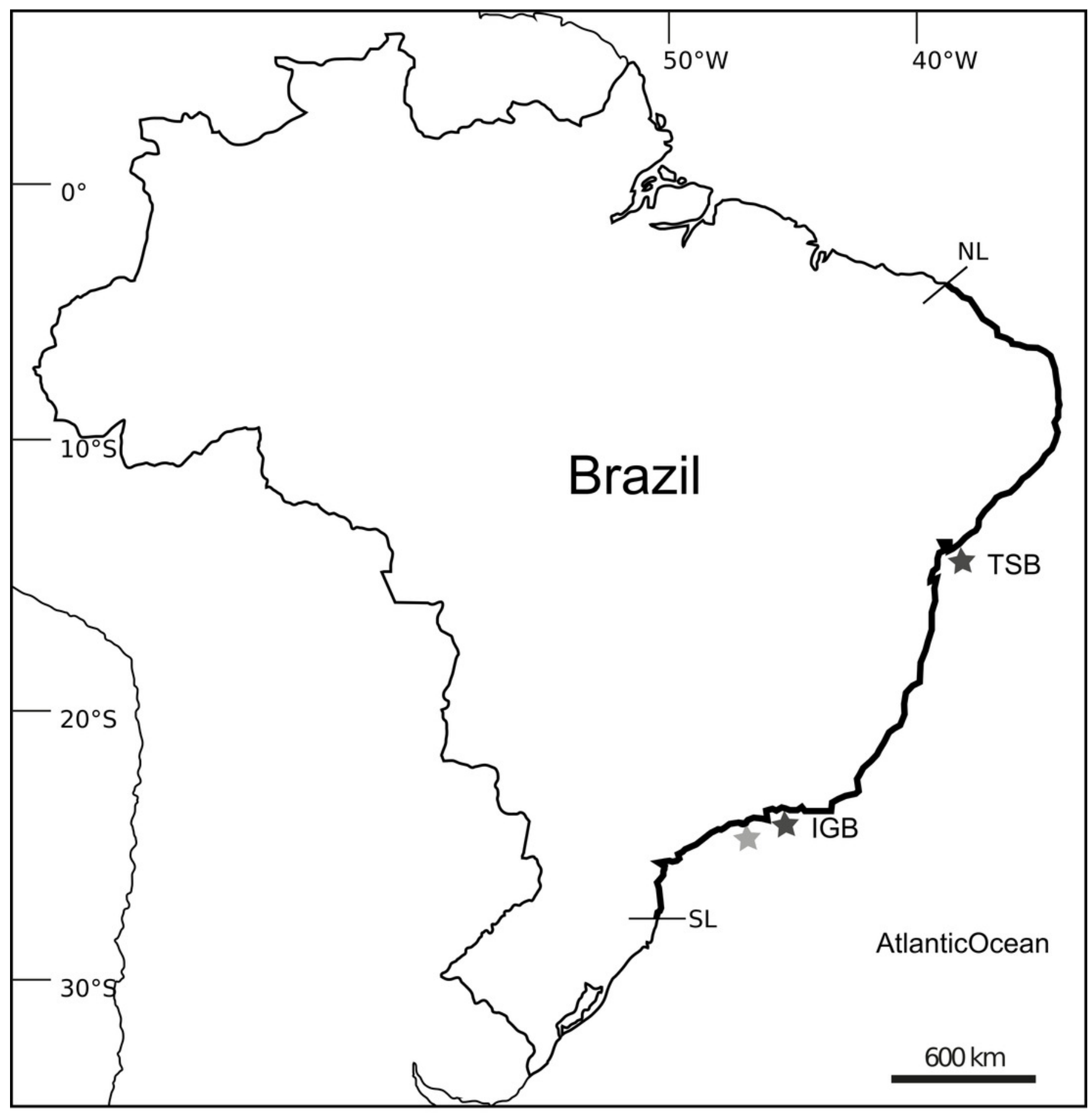


Figure 2

Bayesian clustering analyses for Tubastraea coccinea and $T$. tagusensis.

(a) and (b) shows the most likely $K$-value estimated by the mean of estimated "log probability of data" for each value of $K$ for $T$. coccinea $(K=2)$ and $T$. tagusensis $(K=1)$, respectively; (c) and (d) shows the genetic clusters, were each individual is represented by a vertical bar with different colors indicating the relative proportion of each genetic cluster. TSB = Todos os Santos Bay; IGB = Ilha Grande Bay.
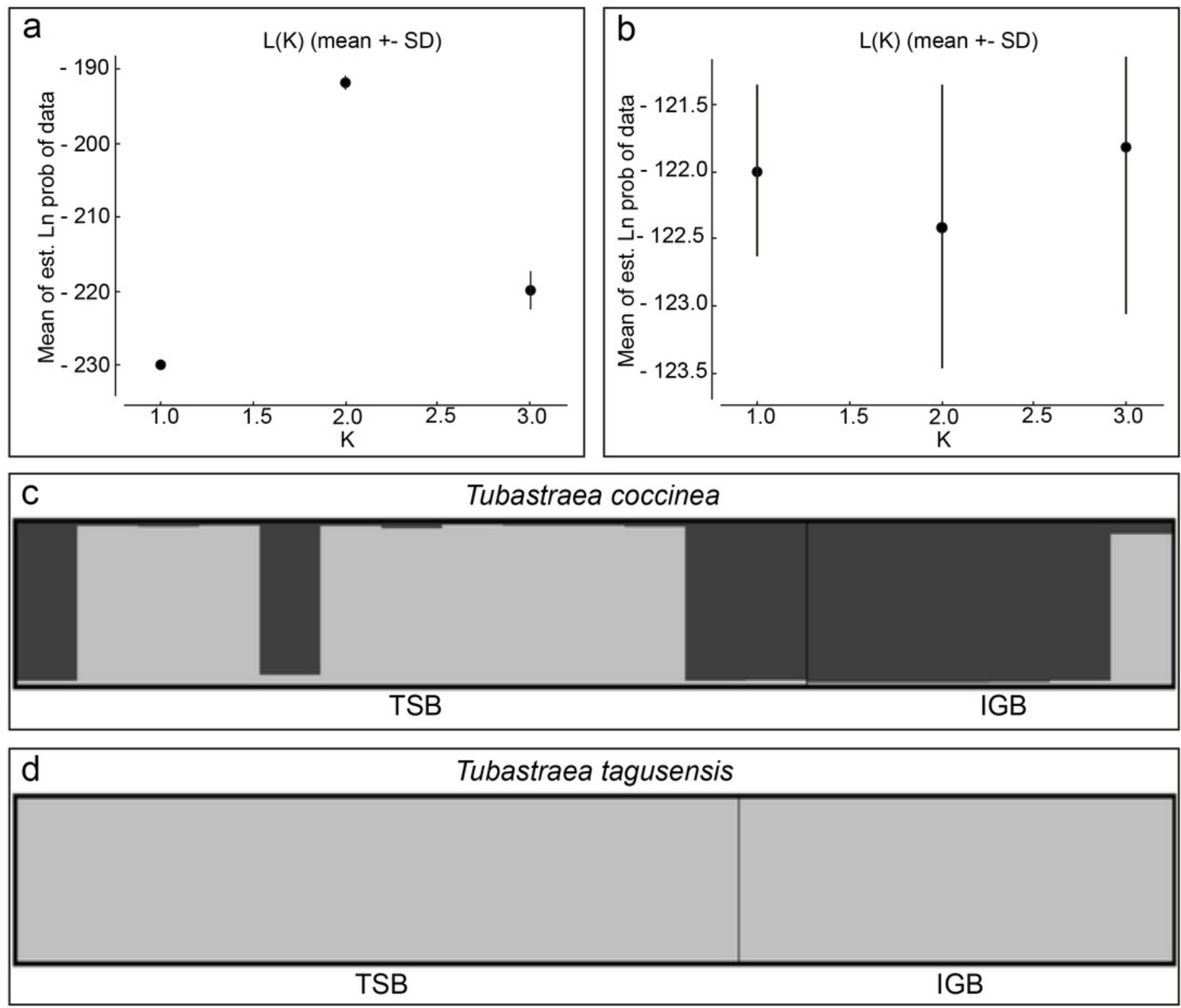


\section{Table $\mathbf{1}$ (on next page)}

Description of Tubastraea coccinea and Tubastraea tagusensis microsatellite loci with their respective GeneBank Accession number.

Forward primers include an M13 sequence (5'-TGTAAAACGACGGCCAGT-3'). 
1 Table 1 Description of Tubastraea coccinea and Tubastraea tagusensis microsatellite loci with their respective GeneBank Accession 2 number. Forward primers include an M13 sequence (5'-TGTAAAACGACGGCCAGT-3')

\begin{tabular}{|c|c|c|c|c|c|c|c|c|c|c|c|c|c|}
\hline $\begin{array}{l}\text { Locus / } \\
\text { Accession } \\
\text { number }\end{array}$ & Primer sequence & $\begin{array}{l}\text { Repeat } \\
\text { motif }\end{array}$ & Species & $\begin{array}{l}\mathrm{T}_{\mathrm{A}}\left({ }^{\circ} \mathrm{C}\right) /[] \\
\mathrm{MgCl}_{2}(\mathrm{mM})\end{array}$ & $\begin{array}{l}\text { Range } \\
\text { (bp) }\end{array}$ & \multicolumn{4}{|c|}{$\mathrm{TSB}(\mathrm{N}=23-\mathrm{Tc} / 24-\mathrm{Tt})$} & \multicolumn{4}{|c|}{ IBG $(\mathrm{N}=24-\mathrm{Tc} / 24-\mathrm{Tt})$} \\
\hline & & & & & & $\mathrm{N}$ & & & & $\mathrm{N}$ & & & \\
\hline & & & & & & $\mathrm{a}$ & Ho & $\mathrm{He}$ & $F_{\text {IS }}$ & a & Ho & $\mathrm{He}$ & $F_{\text {IS }}$ \\
\hline & F: & & & & & & & & & & & & \\
\hline \multirow[t]{2}{*}{$\begin{array}{l}\text { Tco1 / } \\
\text { KY198738 }\end{array}$} & $\begin{array}{l}\text { TGTAAAACGACGGCCAGTACTTCGGT } \\
\text { GATCGGACGAG-PET }\end{array}$ & $(\mathrm{GTT}) 6$ & T. coccinea & $56 / 2$ & $567-600$ & $*$ & & & & & & & \\
\hline & $\begin{array}{l}\text { R: AGCACGGGTACTTGCTTTG } \\
\text { F: }\end{array}$ & & T. tagusensis & $56 / 2$ & & 2 & 0.12 & 0.18 & 0.00 & 1 & 0.00 & 0.00 & NA \\
\hline \multirow{3}{*}{$\begin{array}{l}\text { Tco4 / } \\
\text { KY198739 }\end{array}$} & TGTAAAACGACGGCCAGTGTGGAGAG & & & & & & & & - & & & & \\
\hline & TGAATAAGCTTGGG-NED & (TCA)4 & T. coccinea & $60 / 2$ & $253-259$ & 2 & 1.00 & 0.50 & $\begin{array}{c}1.00 \\
-\end{array}$ & 2 & 1.00 & 0.50 & -1.00 \\
\hline & $\begin{array}{l}\text { R: GCCTGATGGTTTCTTGAGGTC } \\
\text { F: }\end{array}$ & & T. tagusensis & $58 / 2$ & & 2 & 0.40 & 0.32 & 0.14 & 2 & 0.33 & 0.28 & 0.00 \\
\hline \multirow[t]{2}{*}{$\begin{array}{l}\text { Tco5 / } \\
\text { KY198740 }\end{array}$} & $\begin{array}{l}\text { TGTAAAACGACGGCCAGTTCAGGAGC } \\
\text { CGATTAATACCTG-6FAM }\end{array}$ & $(\mathrm{GAAA}) 5$ & T. coccinea & $54 / 2$ & $368-432$ & 5 & 0.50 & 0.76 & 0.39 & 3 & 0.20 & 0.34 & 0.50 \\
\hline & $\begin{array}{l}\text { R: TGTGCAGTGAATGTGCTCAAG } \\
\text { F: }\end{array}$ & & T. tagusensis & $54 / 2.5$ & & 2 & 0.60 & 0.42 & 0,33 & 2 & 0.67 & 0.44 & -0.33 \\
\hline \multirow[t]{2}{*}{$\begin{array}{l}\text { Tco8/ } \\
\text { KY198741 }\end{array}$} & $\begin{array}{l}\text { TGTAAAACGACGGCCAGTGGTGCAGT } \\
\text { GTAAATTGGTTCG-PET }\end{array}$ & $(\mathrm{GGA}) 6$ & T. coccinea & $54 / 2$ & $343-349$ & 2 & 1.00 & 0.50 & $\begin{array}{c}- \\
1.00 \\
-\end{array}$ & 2 & 1.00 & 0.50 & -1.00 \\
\hline & $\begin{array}{l}\text { R: GACAAGTGGAAAGCGGACG } \\
\text { F: }\end{array}$ & & T. tagusensis & $52 / 2$ & & 2 & 1.00 & 0.50 & 1.00 & 2 & 1.00 & 0.50 & -1.00 \\
\hline \multirow[t]{2}{*}{$\begin{array}{l}\text { Tco9/ } \\
\text { KY198742 }\end{array}$} & $\begin{array}{l}\text { TGTAAAACGACGGCCAGTTTGACCAC } \\
\text { GTACTGCCAAG-VIC }\end{array}$ & (TA) 10 & T. coccinea & $60 / 2$ & $347-357$ & $*$ & & & & & & & \\
\hline & $\begin{array}{l}\text { R: TCTGTTCAGAGAGCTCCGC } \\
\text { F: }\end{array}$ & & T. tagusensis & $60 / 2$ & & 2 & 0.20 & 0.18 & 0.00 & 1 & 0.00 & 0.00 & NA \\
\hline \multirow{3}{*}{$\begin{array}{l}\text { Tco29/ } \\
\text { KY198743 }\end{array}$} & TGTAAAACGACGGCCAGTGTGCCCTA & & & & & & & & - & & & & \\
\hline & GGTCCATGGTTT-VIC & $(\mathrm{ATA}) 20$ & T. coccinea & $62 / 1.5$ & $211-222$ & 3 & 0.70 & 0.51 & 0.31 & 3 & 1.00 & 0.57 & -0.71 \\
\hline & $\begin{array}{l}\text { R: CCGGCTTCTATATAGGCTTCC } \\
\text { F: }\end{array}$ & & T. tagusensis & $58 / 2$ & & 3 & 0.20 & 0.46 & 0.64 & 1 & 0.00 & 0.00 & NA \\
\hline \multirow{3}{*}{$\begin{array}{l}\text { Tco30/ } \\
\text { KY198744 }\end{array}$} & TGTAAAACGACGGCCAGTGGGAATTC & & & & & & & & - & & & & \\
\hline & GGATGCAATTAT-6FAM & $(\mathrm{ACAT}) 6$ & T. coccinea & $60 / 1.5$ & $252-264$ & 3 & 1.00 & 0.61 & $\begin{array}{c}0.63 \\
-\end{array}$ & 3 & 1.00 & 0.58 & -0.67 \\
\hline & $\begin{array}{l}\text { R: CTCTGTGGAATGAGCTGCAA } \\
\text { F: }\end{array}$ & & T. tagusensis & $60 / 2.25$ & & 2 & 1.00 & 0.50 & 1.00 & 2 & 1.00 & 0.50 & -1.00 \\
\hline $\begin{array}{l}\text { Tco32a/ } \\
\text { KY198745 }\end{array}$ & $\begin{array}{l}\text { TGTAAAACGACGGCCAGTGCGTGGTC } \\
\text { TGGTCTTTTCAT-6FAM }\end{array}$ & (ATA) 13 & T. tagusensis & $58 / 2$ & $240-246$ & 2 & 1.00 & 0.50 & $\begin{array}{c}- \\
1.00\end{array}$ & 2 & 1.00 & 0.50 & -1.00 \\
\hline
\end{tabular}




\begin{tabular}{|c|c|c|c|c|c|c|c|c|c|c|c|c|c|}
\hline \multirow{3}{*}{$\begin{array}{l}\text { Tco32b/ } \\
\text { KY198745 }\end{array}$} & \multicolumn{13}{|l|}{ R: ACCCACTTTGAGGTGTTTGG } \\
\hline & & & & & & & & & - & & & & \\
\hline & $\begin{array}{l}* \\
\mathrm{~F}:\end{array}$ & & T. tagusensis & & $270-276$ & 2 & 1.00 & 0.50 & 1.00 & 3 & 1.00 & 0.61 & $-0,50$ \\
\hline \multirow[t]{2}{*}{$\begin{array}{l}\text { Tco34/ } \\
\text { KY198746 }\end{array}$} & $\begin{array}{l}\text { TGTAAAACGACGGCCAGTGCGCCTAC } \\
\text { TACCACACGAAT-PET }\end{array}$ & (TTA) 19 & T. coccinea & $58 / 2$ & $189-217$ & 2 & 0.38 & 0.31 & $\begin{array}{c}- \\
0.20 \\
-\end{array}$ & 2 & 0.17 & 0.15 & 0.00 \\
\hline & $\begin{array}{l}\text { R: TCCTTTCTACAGCGCACCTT } \\
\text { F: }\end{array}$ & & T. tagusensis & $58 / 2$ & & 3 & 0.80 & 0.58 & 0.28 & 3 & 1.00 & 0.61 & -0.50 \\
\hline \multirow[t]{2}{*}{$\begin{array}{l}\text { Tco36/ } \\
\text { KY198747 }\end{array}$} & $\begin{array}{l}\text { TGTAAAACGACGGCCAGTGCAATGAC } \\
\text { AACAGCCAGAAC-VIC }\end{array}$ & (ATA) 15 & T. coccinea & $58 / 1.5$ & $238-250$ & $* *$ & & & & $* *$ & & & \\
\hline & $\begin{array}{l}\text { R: TTTCGTCTGCCACATTCTTG } \\
\text { F: }\end{array}$ & & & & & & & & & & & & \\
\hline \multirow{3}{*}{$\begin{array}{l}\text { Tco37/ } \\
\text { KY198748 }\end{array}$} & TGTAAAACGACGGCCAGTAAACATTC & & & & & & & & - & & & & \\
\hline & GATTCCCACTCG-NED & $(\mathrm{CTA}) 24$ & T. coccinea & $62 / 1.5$ & $242-263$ & 4 & 1.00 & 0.74 & $\begin{array}{c}0.32 \\
-\end{array}$ & 2 & 1.00 & 0.50 & -1.00 \\
\hline & $\begin{array}{l}\text { R: ACCCGGCCACTAATATTTCC } \\
\text { F: }\end{array}$ & & T. tagusensis & $62 / 1.5$ & & 3 & 1.00 & 0.62 & 0.50 & 3 & 1.00 & 0.61 & -0.50 \\
\hline \multirow[t]{2}{*}{$\begin{array}{l}\text { Tco38/ } \\
\text { KY198749 }\end{array}$} & $\begin{array}{l}\text { TGTAAAACGACGGCCAGTTTTGAGTTTG } \\
\text { AGTTTATTGACTCCTT-NED }\end{array}$ & (TACA)6 & T. coccinea & $58 / 1.5$ & $227-235$ & $* *$ & & & & $* *$ & & & \\
\hline & R: GGAGTAAGCTTAGAGGGGTGCT & & & & & & & & & & & & \\
\hline
\end{tabular}

$3 \mathrm{~T}_{\mathrm{A}}=$ primer's annealing temperature; [ $] \mathrm{MgCl}_{2}=$ concentration of magnesium chloride; $\mathrm{N}=$ number of individuals genotyped; $\mathrm{Na}=$ number of alleles; $\mathrm{He}=$

4 expected heterozygosity; Ho $=$ observed heterozygosity; $F_{\mathrm{IS}}=$ inbreeding coefficient (negative values indicate an excess of heterozygotes); $(*)=$ loci with

5 evidence of linkage disequilibrium. $(* *)=$ loci with evidence of null alleles 


\section{Table 2 (on next page)}

Genetic diversity of Tubastraea coccinea and T. tagusensis in two localities on the Southwestern Atlantic Ocean, Todos os Santos Bay (TSB) and Ilha Grande Bay (IGB), Brazil. 
1 Table 2 Genetic diversity of Tubastraea coccinea and T. tagusensis in two localities on the Southwestern Atlantic Ocean, Todos os 2 Santos Bay (TSB) and Ilha Grande Bay (IGB), Brazil

\begin{tabular}{ccccccccccccc}
\hline Specie & Location & N & MLG & MLL & R & V & A & AR & Ap & Ho & He & $F_{\text {IS }}$ \\
\hline \multirow{2}{*}{ T. coccinea } & TSB & 23 & 13 & 13 & 0.55 & 0.845 & 21 & 2.74 & 4 & 0.80 & 0.56 & -0.380 \\
& IGB & 24 & 6 & 6 & 0.21 & $1.13 \mathrm{e}-16$ & 17 & 2.18 & 0 & 0.77 & 0.45 & -0.651 \\
\multirow{2}{*}{ T. tagusensis } & TSB & 24 & 7 & 5 & 0.17 & 0.54 & 25 & 1.98 & 4 & 0.67 & 0.43 & -0.468 \\
& IGB & 24 & 6 & 3 & 0.09 & $1.04 \mathrm{e}-16$ & 22 & 1.87 & 1 & 0.64 & 0.37 & -0.615 \\
\hline
\end{tabular}

$3 \overline{\mathrm{N}}=$ Number of individuals sampled; $\mathrm{MLG}=$ multilocus genotype; $\mathrm{MLL}=$ multilocus lineages; $\mathrm{R}=$ clonal richness; $\mathrm{V}=$ genotypic evenness; $\beta=$ pareteo

4 distribution; $\mathrm{A}=$ alleles number; $\mathrm{AR}=$ allele richness; $\mathrm{Ap}=$ number of private alleles; $\mathrm{Ho}=$ observed heterozigosities; $\mathrm{He}=\operatorname{expected~heterozigosities;~} F_{\mathrm{IS}}=$ 5 inbreeding coefficient 